\title{
Amines are likely to enhance neutral and ion-induced sulfuric acid-water nucleation in the atmosphere more effectively than ammonia
}

\author{
T. Kurtén, V. Loukonen, H. Vehkamäki, and M. Kulmala \\ Division of Atmospheric Sciences and Geophysics, Dept. of Physics, P.O.Box 64, 00014 University of Helsinki, Finland \\ Received: 12 February 2008 - Published in Atmos. Chem. Phys. Discuss.: 16 April 2008 \\ Revised: 17 June 2008 - Accepted: 17 June 2008 - Published: 30 July 2008
}

\begin{abstract}
We have studied the structure and formation thermodynamics of dimer clusters containing $\mathrm{H}_{2} \mathrm{SO}_{4}$ or $\mathrm{HSO}_{4}^{-}$ together with ammonia and seven different amines possibly present in the atmosphere, using the high-level ab initio methods RI-MP2 and RI-CC2. As expected from e.g. proton affinity data, the binding of all studied amine- $\mathrm{H}_{2} \mathrm{SO}_{4}$ complexes is significantly stronger than that of $\mathrm{NH}_{3} \bullet \mathrm{H}_{2} \mathrm{SO}_{4}$, while most amine- $\mathrm{HSO}_{4}^{-}$complexes are only somewhat more strongly bound than $\mathrm{NH}_{3} \bullet \mathrm{HSO}_{4}^{-}$. Further calculations on larger cluster structures containing dimethylamine or ammonia together with two $\mathrm{H}_{2} \mathrm{SO}_{4}$ molecules or one $\mathrm{H}_{2} \mathrm{SO}_{4}$ molecule and one $\mathrm{HSO}_{4}^{-}$ion demonstrate that amines, unlike ammonia, significantly assist the growth of not only neutral but also ionic clusters along the $\mathrm{H}_{2} \mathrm{SO}_{4}$ co-ordinate. A sensitivity analysis indicates that the difference in complexation free energies for amine- and ammonia-containing clusters is large enough to overcome the mass-balance effect caused by the fact that the concentration of amines in the atmosphere is probably 2 or 3 orders of magnitude lower than that of ammonia. This implies that amines might be more important than ammonia in enhancing neutral and especially ioninduced sulfuric acid-water nucleation in the atmosphere.
\end{abstract}

\section{Introduction}

Based on experimental and modeling results, particle formation by nucleation in the lower atmosphere is thought to involve water and sulfuric acid, with possible contributions from ions, ammonia or various organic molecules (Korhonen et al., 1999; Kulmala et al., 2000; Anttila et al., 2005).

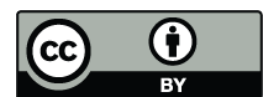

Correspondence to: T. Kurtén (theo.kurten@helsinki.fi)
Recent experimental results (Kulmala et al., 2007) indicate that neutral mechanisms are likely to dominate nucleation at least in boreal forest areas, with ion-induced nucleation playing only a small role. The effect of ammonia in the sulfuric acid-water nucleation process has been studied extensively. Experimental results (Ball et al., 1999) suggest that ammonia enhances nucleation by 1-2 orders of magnitude, whereas theoretical studies have previously given varying predictions. Recent quantum chemical calculations demonstrate that when appropriate methods are applied to sufficiently large cluster structures (containing two or more sulfuric acid molecules), also molecular-level simulations reproduce the experimentally observed nucleation-enhancing effect (Kurtén et al., 2007a; Torpo et al., 2007; Nadykto and $\mathrm{Yu}, 2007)$. Experiments (Ball et al., 1999), updated and corrected classical nucleation theory simulations (Anttila et al., 2005) and quantum chemical calculations are now all in qualitative agreement, and indicate a modest enhancement of sulfuric acid-water nucleation by ammonia in most atmospheric conditions.

Based on both experimental and theoretical results (Kulmala et al., 2004a), neutral binary sulfuric acid-water nucleation alone can not explain most of the new-particle formation events observed in the atmosphere. Also, in a recent study, Laakso et al. (2007) measured boundary layer particle formation using a hot-air balloon, and came to the conclusion that ion-induced nucleation of water-sulfuric acid clusters can not explain the observed formation of charged nanoparticles. In numerical simulations based on the thermodynamic data of Lovejoy et al. (2004), they found that that binary ion-induced nucleation could not explain most of the observed nucleation even if sulfuric acid concentrations twice as large as those estimated from the measured $\mathrm{SO}_{2}$ concentrations were used. This would suggest that some other

Published by Copernicus Publications on behalf of the European Geosciences Union. 
compounds are involved in stabilizing the clusters. Kurtén et al. (2007b) recently computed formation energies for small neutral and ionic sulfuric acid-water and sulfuric acid-waterammonia clusters, and found that the $\mathrm{HSO}_{4}^{-}$ion is very weakly bound to ammonia. This result was confirmed by Ortega et al. (2008), who also computed formation energies of charged clusters containing $\mathrm{HSO}_{4}^{-}, \mathrm{NH}_{3}$ and up to three $\mathrm{H}_{2} \mathrm{SO}_{4}$ molecules, and found that ammonia does not enhance ion-induced sulfuric acid-water nucleation. Some other compound or family of compounds are thus needed to explain the experimental observations of Laakso et al. (2007).

Like ammonia, amines are able to form e.g. nitrate or sulfate salts in atmospheric conditions. Indeed, chemical intuition and proton affinity data (Hunter and Lias, 1998) indicates that proton transfer should occur more easily for amine-acid clusters than for ammonia-acid clusters, leading to stronger binding. Based on laboratory chamber experiments and quantum chemical calculations on crystal structures, Murphy et al. (2007) recently reported that for nucleation processes involving nitric acid, amines such as diethylamine may be more effective than ammonia in forming new particles. Based on a combination of smog chamber experiments and field measurements, Angelino et al. (2001) suggested that amine chemistry "may play a significant role in particle formation in regions with high amine concentrations" due to both acid-base and oxidation reactions. Also, in an experimental study by Mäkelä et al. (2001) dimethylammonium, the ionic form of dimethylamine, was found to be present in aerosol particles during particle formation events and/or the immediately following particle growth processes in Hyytiälä, Southern Finland. The relative difference between event and non-event dimethylamine concentrations in the aerosol phase were approximately 50 -fold, indicating that dimethylamine is involved in particle formation. In view of these results, it is possible that amines, instead of ammonia, are the primary enhancers of sulfuric acid-water nucleation, or may at least significantly contribute to particle formation in the atmosphere.

As a first step in the investigation of the atmospheric relevance of sulfuric acid-amine clusters, we have calculated the structure and binding energies of clusters comprising one sulfuric acid and either ammonia, methylamine, dimethylamine, trimethylamine, ethylamine, diethylamine, triethylamine or ethylmethylamine, using high-level ab initio methods. The same calculations were then performed with the hydrogensulfate ion instead of sulfuric acid. Based on the results of these calculations, as well as the results of Mäkelä et al. (2001), further calculations were then carried out on clusters containing dimethylamine or ammonia together with either two sulfuric acid molecules or one sulfuric acid molecule and one hydrogensulfate ion. Qualitative estimates for the formation enthalpies, entropies and Gibbs free energies were then computed for all clusters using the harmonic oscillator and rigid rotor approximations.

\section{Computational details}

All calculations were performed using the Turbomole v.5.8. program suite (Ahlrichs et al., 1989; Häser and Ahlrichs, 1989). For structure optimizations and vibrational frequency calculations, we used the RI-MP2 method (Weigend and Häser, 1997; Weigend et al., 1998) with the frozen-core approximation and the aug-cc-pV(D+d)Z basis set (Dunning et al., 2001), though some test optimizations were also performed using the larger aug-cc-pV(T+d)Z basis set (Dunning et al., 2001) (see the supporting information for details). The auxiliary basis sets needed for the RI expansion are given by Weigend et al. (2002). Final electronic energies were computed using the RI-MP2 and RI-CC2 methods (Christiansen et al., 1995) and the aug-cc-pV(T+d)Z basis set. Though the correlation energy computed by the RI-CC2 method is more accurate than that given by RI-MP2, the RI-CC2 method is primarily designed to compute molecular properties rather than energies, and it should therefore be noted that the results are thus not as accurate as those computed using, for example, the more demanding coupled cluster methods CCSD or $\operatorname{CCSD}(\mathrm{T})$. In a recent high-level study on small neutral and charged sulfuric acid - water clusters (Kurtén et al., 2007b), we have shown that at the RI-MP2 level, increasing the basis set size beyond aug-cc-pV(T+d)Z has only a small effect on the intermolecular binding (complexation) energies. The commonly used counterpoise (CP) correction seems to significantly exaggerate basis-set related errors for large basis sets containing multiple diffuse basis functions (Kurtén et al., 2007b; Feller, 1992), and is therefore not computed here. The convergence with respect to the electronic energy in the self-consistent field (SCF) step was $10^{-7}$ a.u. (atomic units), and the convergence with respect to the gradient was $10^{-4}$ a.u. For the numerical frequency calculations, a stepsize of 0.01 a.u. and a SCF convergence limit of $10^{-8}$ a.u. were used, based on test calculations carried out as part of an earlier study on sulfuric acid-ammonia clusters (Kurtén et al., 2007c). As the emphasis of this study is on comparing complex formation free energies of amine- and ammoniacontaining clusters rather than on computing accurate absolute free energies, no scaling factors were used to account for vibrational anharmonicity. For details on the effect of anharmonicity on this type of cluster structures, and on the difficulties in constructing reliable scaling factor approaches for free energy calculations, see Kurtén et al. (2007b).

\section{Results and discussion}

The structures of the studied dimer clusters are shown in Figs.1-2. Figure 1 contains the neutral $\mathrm{H}_{2} \mathrm{SO}_{4}$ amine dimer complexes, while Fig. 2 contains the ionic $\mathrm{HSO}_{4}^{-}$-amine dimer complexes. The structures are drawn using the MOLEKEL 4.3 visualization package (Portmann, 2002). The corresponding electronic energies, 


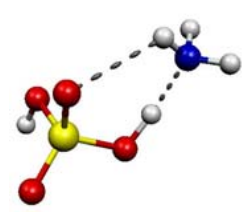

a)

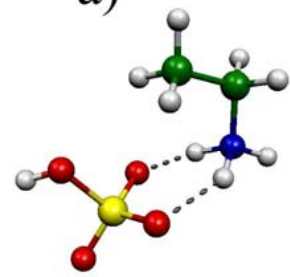

e)

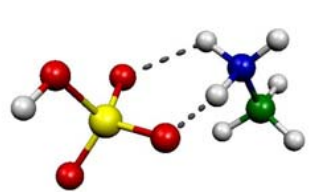

b)

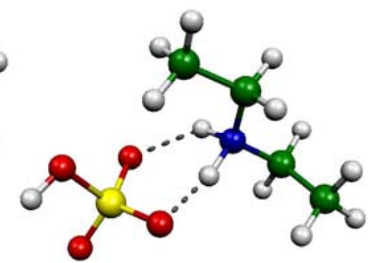

f)

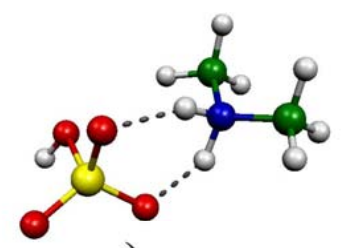

c)

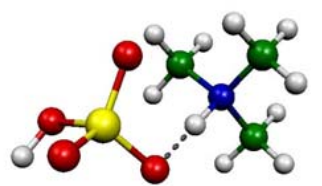

d)

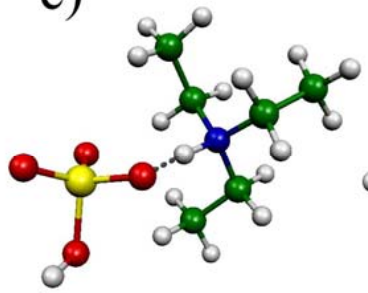

g)

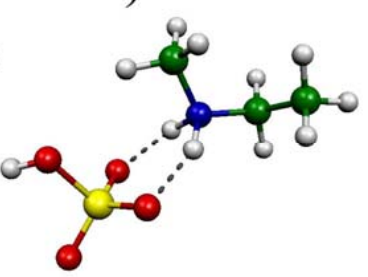

h)

Fig. 1. The structures of dimer clusters containing sulfuric acid and ammonia or various amines: a) $\left.\mathrm{H}_{2} \mathrm{SO}_{4} \bullet \mathrm{NH}_{3}, \mathbf{b}\right) \mathrm{H}_{2} \mathrm{SO}_{4} \bullet \mathrm{CH}_{3} \mathrm{NH}_{2}$, c) $\mathrm{H}_{2} \mathrm{SO}_{4} \bullet\left(\mathrm{CH}_{3}\right)_{2} \mathrm{NH}$, d) $\mathrm{H}_{2} \mathrm{SO}_{4} \bullet\left(\mathrm{CH}_{3}\right)_{3} \mathrm{~N}$, e) $\mathrm{H}_{2} \mathrm{SO}_{4} \bullet \mathrm{CH}_{3} \mathrm{CH}_{2} \mathrm{NH}_{2}$, f) $\mathrm{H}_{2} \mathrm{SO}_{4} \bullet\left(\mathrm{CH}_{3} \mathrm{CH}_{2}\right)_{2} \mathrm{NH}_{2}$ g) $\mathrm{H}_{2} \mathrm{SO}_{4} \bullet\left(\mathrm{CH}_{3} \mathrm{CH}_{2}\right)_{3} \mathrm{~N}$, h) $\mathrm{H}_{2} \mathrm{SO}_{4} \bullet\left(\mathrm{CH}_{3} \mathrm{CH}_{2}\right) \mathrm{NH}\left(\mathrm{CH}_{3}\right)$. Hydrogen bonds are indicated by dashed lines. Color coding: yellow = sulfur, red $=$ oxygen, blue $=$ nitrogen, green $=$ carbon and white $=$ hydrogen .

Table 1. Electronic energies computed for the dimer formation reactions at different levels of theory. DZ and TZ correspond to aug-cc$\mathrm{pV}(\mathrm{D}+\mathrm{d}) \mathrm{Z}$ and aug-cc-pV(T+d)Z, respectively. All values correspond to geometries optimized at the RI-MP2/aug-cc-pV(D+d)Z level.

\begin{tabular}{|c|c|c|c|}
\hline Reaction & $\begin{array}{c}\Delta E_{0}, \\
\text { RI-MP2/DZ } \\
\text { kcal/mol }\end{array}$ & $\begin{array}{c}\Delta E_{0}, \\
\text { RI-MP2/TZ } \\
\text { kcal/mol }\end{array}$ & $\begin{array}{c}\Delta E_{0}, \\
\mathrm{RI}-\mathrm{CC} 2 / \mathrm{TZ} \\
\mathrm{kcal} / \mathrm{mol}\end{array}$ \\
\hline $\mathrm{H}_{2} \mathrm{SO}_{4}+\mathrm{NH}_{3} \leftrightarrow \mathrm{H}_{2} \mathrm{SO}_{4} \bullet \mathrm{NH}_{3}$ & -16.99 & -17.08 & -17.37 \\
\hline $\mathrm{H}_{2} \mathrm{SO}_{4}+\mathrm{CH}_{3} \mathrm{NH}_{2} \leftrightarrow \mathrm{H}_{2} \mathrm{SO}_{4} \bullet \mathrm{CH}_{3} \mathrm{NH}_{2}$ & -21.91 & -21.90 & -22.84 \\
\hline $\mathrm{H}_{2} \mathrm{SO}_{4}+\mathrm{CH}_{3} \mathrm{CH}_{2} \mathrm{NH}_{2} \leftrightarrow \mathrm{H}_{2} \mathrm{SO}_{4} \bullet \mathrm{CH}_{3} \mathrm{CH}_{2} \mathrm{NH}_{2}$ & -23.78 & -23.40 & -24.53 \\
\hline $\mathrm{H}_{2} \mathrm{SO}_{4}+\left(\mathrm{CH}_{3}\right)_{2} \mathrm{NH} \leftrightarrow \mathrm{H}_{2} \mathrm{SO}_{4} \bullet\left(\mathrm{CH}_{3}\right)_{2} \mathrm{NH}$ & -26.73 & -26.06 & -27.22 \\
\hline $\mathrm{H}_{2} \mathrm{SO}_{4}+\left(\mathrm{CH}_{3} \mathrm{CH}_{2}\right)_{2} \mathrm{NH} \leftrightarrow \mathrm{H}_{2} \mathrm{SO}_{4} \bullet\left(\mathrm{CH}_{3} \mathrm{CH}_{2}\right)_{2} \mathrm{NH}$ & -30.05 & -29.09 & -30.19 \\
\hline $\mathrm{H}_{2} \mathrm{SO}_{4}+\left(\mathrm{CH}_{3}\right)_{3} \mathrm{~N} \leftrightarrow \mathrm{H}_{2} \mathrm{SO}_{4} \bullet\left(\mathrm{CH}_{3}\right)_{3} \mathrm{~N}$ & -28.71 & -27.51 & -28.47 \\
\hline $\mathrm{H}_{2} \mathrm{SO}_{4}+\left(\mathrm{CH}_{3} \mathrm{CH}_{2}\right)_{3} \mathrm{~N} \leftrightarrow \mathrm{H}_{2} \mathrm{SO}_{4} \bullet\left(\mathrm{CH}_{3} \mathrm{CH}_{2}\right)_{3} \mathrm{~N}$ & -33.09 & -31.05 & -32.16 \\
\hline $\mathrm{H}_{2} \mathrm{SO}_{4}+\left(\mathrm{CH}_{3} \mathrm{CH}_{2}\right) \mathrm{NH}\left(\mathrm{CH}_{3}\right) \leftrightarrow \mathrm{H}_{2} \mathrm{SO}_{4} \bullet\left(\mathrm{CH}_{3} \mathrm{CH}_{2}\right) \mathrm{NH}\left(\mathrm{CH}_{3}\right)$ & -28.14 & -27.34 & -28.48 \\
\hline $\mathrm{HSO}_{4}^{-}+\mathrm{NH}_{3} \leftrightarrow \mathrm{HSO}_{4}^{-} \bullet \mathrm{NH}_{3}$ & -10.79 & -10.60 & -10.85 \\
\hline $\mathrm{HSO}_{4}^{-}+\mathrm{CH}_{3} \mathrm{NH}_{2} \leftrightarrow \stackrel{4}{\mathrm{HSO}_{4}^{-}} \bullet \mathrm{CH}_{3} \mathrm{NH}_{2}$ & -10.66 & -9.79 & -10.12 \\
\hline $\mathrm{HSO}_{4}^{-}+\mathrm{CH}_{3} \mathrm{CH}_{2} \mathrm{NH}_{2} \leftrightarrow \mathrm{HSO}_{4}^{-} \bullet \mathrm{CH}_{3} \mathrm{CH}_{2} \mathrm{NH}_{2}$ & -12.07 & -10.92 & -11.36 \\
\hline $\mathrm{HSO}_{4}^{-}+\left(\mathrm{CH}_{3}\right)_{2} \mathrm{NH} \leftrightarrow \mathrm{HSO}_{4}^{-} \bullet\left(\mathrm{CH}_{3}\right)_{2} \mathrm{NH}$ & -14.06 & -13.65 & -14.25 \\
\hline 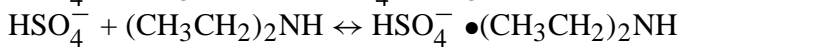 & -15.47 & -14.56 & -15.33 \\
\hline $\mathrm{HSO}_{4}^{-}+\left(\mathrm{CH}_{3}\right)_{3} \mathrm{~N} \leftrightarrow \mathrm{HSO}_{4}^{-} \bullet\left(\mathrm{CH}_{3}\right)_{3} \mathrm{~N}$ & -13.12 & -12.09 & -12.80 \\
\hline $\mathrm{HSO}_{4}^{-}+\left(\mathrm{CH}_{3} \mathrm{CH}_{2}\right)_{3} \mathrm{~N} \leftrightarrow \mathrm{HSO}_{4}^{-} \bullet\left(\mathrm{CH}_{3} \mathrm{CH}_{2}\right)_{3} \mathrm{~N}$ & -15.61 & -13.81 & -14.78 \\
\hline $\mathrm{HSO}_{4}^{-}+\left(\mathrm{CH}_{3} \mathrm{CH}_{2}\right) \mathrm{NH}\left(\mathrm{CH}_{3}\right) \stackrel{4}{\leftrightarrow} \mathrm{HSO}_{4}^{-} \bullet\left(\mathrm{CH}_{3} \mathrm{CH}_{2}\right) \mathrm{NH}\left(\mathrm{CH}_{3}\right)$ & -15.03 & -14.31 & -15.03 \\
\hline
\end{tabular}

enthalpies and entropies are presented in the supporting information along with the coordinates for all studied cluster structures (http://www.atmos-chem-phys.net/8/4095/ 2008/acp-8-4095-2008-supplement.pdf).

The electronic energies for the formation of the various dimer clusters from their constituent molecules are shown in Table 1. The values have been computed at three levels of theory: RI-MP2/aug-cc-pV(D+d)Z, RI-MP2/aug-cc-
$\mathrm{pV}(\mathrm{T}+\mathrm{d}) \mathrm{Z}$, and RI-CC2/aug-cc-pV(T+d)Z. Table 2 lists the corresponding enthalpies, entropies and Gibbs free energies for complex formation at $298 \mathrm{~K}$ and $1 \mathrm{~atm}$ reference pressure, computed using the RI-MP2/aug-cc-pV(D+d)Z harmonic vibrational frequencies with the RI-CC2/aug-cc-pV(T+d)Z electronic energies. The use of harmonic vibrational frequencies for the $\mathrm{HSO}_{4}^{-}$ion causes moderately large errors in the absolute values of the complexation free energy for the ionic 


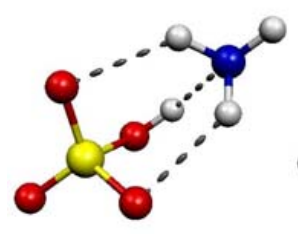

a)

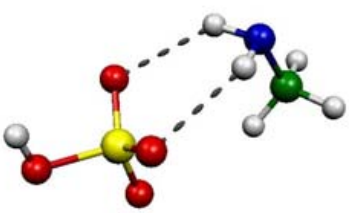

b)

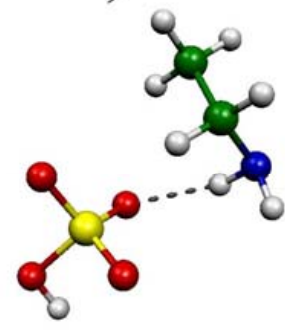

e)

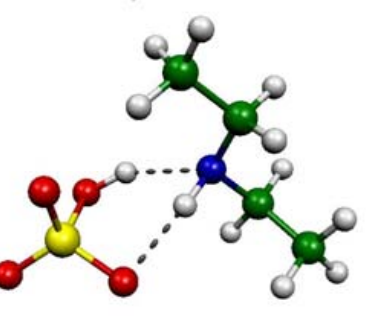

f)

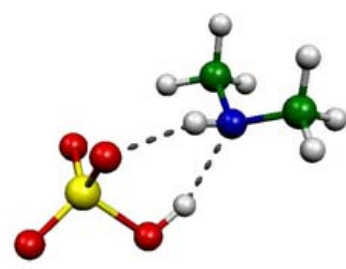

c)

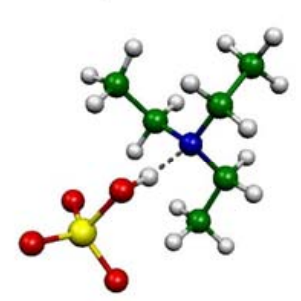

g)

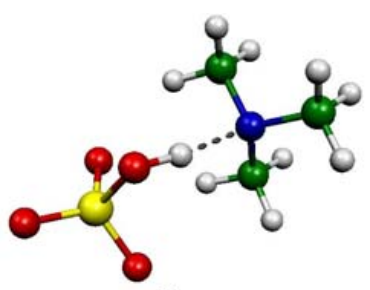

d)

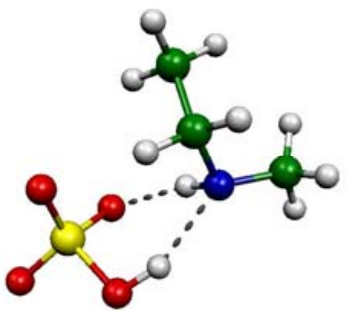

h)

Fig. 2. The structures of ionic dimer clusters containing a hydrogensulfate ion and ammonia or various amines: a) $\mathrm{HSO}_{4}^{-} \bullet \mathrm{NH}_{3}$, b) $\mathrm{HSO}_{4}^{-} \bullet \mathrm{CH}_{3} \mathrm{NH}_{2}$, c) $\mathrm{HSO}_{4}^{-} \bullet\left(\mathrm{CH}_{3}\right)_{2} \mathrm{NH}$, d) $\mathrm{HSO}_{4}^{-} \bullet\left(\mathrm{CH}_{3}\right)_{3} \mathrm{~N}$, e) $\mathrm{HSO}_{4}^{-} \bullet \mathrm{CH}_{3} \mathrm{CH}_{2} \mathrm{NH}_{2}$, f) $\mathrm{HSO}_{4}^{-} \bullet\left(\mathrm{CH}_{3} \mathrm{CH}_{2}\right)_{2} \mathrm{NH}$, g) $\left.\mathrm{HSO}_{4}^{-} \bullet\left(\mathrm{CH}_{3} \mathrm{CH}_{2}\right)_{3} \mathrm{~N}, \mathbf{h}\right) \mathrm{HSO}_{4}^{-} \bullet\left(\mathrm{CH}_{3} \mathrm{CH}_{2}\right) \mathrm{NH}\left(\mathrm{CH}_{3}\right)$. Hydrogen bonds are indicated by dashed lines. Color coding as in Fig. 1.

Table 2. Enthalpies, entropies and Gibbs free energies computed for the dimer formation reactions at $298 \mathrm{~K}$ and 1 atm reference pressure for all reactants. All values correspond to RI-MP2/aug-cc-pV(D+d)Z geometries and harmonic vibrational frequencies and RI-CC2/aug-cc$\mathrm{pV}(\mathrm{T}+\mathrm{d}) \mathrm{Z}$ electronic energies.

\begin{tabular}{|c|c|c|c|}
\hline Reaction & $\begin{array}{c}\Delta H(298 \mathrm{~K}) \\
\mathrm{kcal} / \mathrm{mol}\end{array}$ & $\begin{array}{c}\Delta S(298 \mathrm{~K}) \\
\mathrm{cal} / \mathrm{Kmol}\end{array}$ & $\begin{array}{r}\Delta G(298 \mathrm{~K}) \\
\mathrm{kcal} / \mathrm{mol}\end{array}$ \\
\hline $\mathrm{H}_{2} \mathrm{SO}_{4}+\mathrm{NH}_{3} \leftrightarrow \mathrm{H}_{2} \mathrm{SO}_{4} \bullet \mathrm{NH}_{3}$ & -16.06 & -31.60 & -6.64 \\
\hline $\mathrm{H}_{2} \mathrm{SO}_{4}+\mathrm{CH}_{3} \mathrm{NH}_{2} \leftrightarrow \mathrm{H}_{2} \mathrm{SO}_{4} \bullet \mathrm{CH}_{3} \mathrm{NH}_{2}$ & -20.87 & -36.62 & -9.95 \\
\hline $\mathrm{H}_{2} \mathrm{SO}_{4}+\mathrm{CH}_{3} \mathrm{CH}_{2} \mathrm{NH}_{2} \leftrightarrow \mathrm{H}_{2} \mathrm{SO}_{4} \bullet \mathrm{CH}_{3} \mathrm{CH}_{2} \mathrm{NH}_{2}$ & -22.45 & -38.22 & -11.06 \\
\hline $\mathrm{H}_{2} \mathrm{SO}_{4}+\left(\mathrm{CH}_{3}\right)_{2} \mathrm{NH} \leftrightarrow \mathrm{H}_{2} \mathrm{SO}_{4} \bullet\left(\mathrm{CH}_{3}\right)_{2} \mathrm{NH}$ & -24.73 & -37.14 & -13.66 \\
\hline $\mathrm{H}_{2} \mathrm{SO}_{4}+\left(\mathrm{CH}_{3} \mathrm{CH}_{2}\right)_{2} \mathrm{NH} \leftrightarrow \mathrm{H}_{2} \mathrm{SO}_{4} \bullet\left(\mathrm{CH}_{3} \mathrm{CH}_{2}\right)_{2} \mathrm{NH}$ & -27.73 & -37.65 & -16.53 \\
\hline $\mathrm{H}_{2} \mathrm{SO}_{4}+\left(\mathrm{CH}_{3}\right)_{3} \mathrm{~N} \leftrightarrow \mathrm{H}_{2} \mathrm{SO}_{4} \bullet\left(\mathrm{CH}_{3}\right)_{3} \mathrm{~N}$ & -26.01 & -36.08 & -15.26 \\
\hline $\mathrm{H}_{2} \mathrm{SO}_{4}+\left(\mathrm{CH}_{3} \mathrm{CH}_{2}\right)_{3} \mathrm{~N} \leftrightarrow \mathrm{H}_{2} \mathrm{SO}_{4} \bullet\left(\mathrm{CH}_{3} \mathrm{CH}_{2}\right)_{3} \mathrm{~N}$ & -29.54 & -41.04 & -17.30 \\
\hline $\mathrm{H}_{2} \mathrm{SO}_{4}+\left(\mathrm{CH}_{3} \mathrm{CH}_{2}\right) \mathrm{NH}\left(\mathrm{CH}_{3}\right) \leftrightarrow \mathrm{H}_{2} \mathrm{SO}_{4} \bullet\left(\mathrm{CH}_{3} \mathrm{CH}_{2}\right) \mathrm{NH}\left(\mathrm{CH}_{3}\right)$ & -25.94 & -36.78 & -14.97 \\
\hline $\mathrm{HSO}_{4}^{-}+\mathrm{NH}_{3} \leftrightarrow \mathrm{HSO}_{4}^{-} \bullet \mathrm{NH}_{3}$ & -9.07 & -40.57 & 1.75 \\
\hline $\mathrm{HSO}_{4}^{-}+\mathrm{CH}_{3} \mathrm{NH}_{2} \leftrightarrow \stackrel{+}{\mathrm{HSO}_{4}^{-}} \bullet \mathrm{CH}_{3} \mathrm{NH}_{2}$ & -8.68 & -33.14 & 1.20 \\
\hline $\mathrm{HSO}_{4}^{-}+\mathrm{CH}_{3} \mathrm{CH}_{2} \mathrm{NH}_{2} \leftrightarrow \mathrm{HSO}_{4}^{-} \bullet \mathrm{CH}_{3} \mathrm{CH}_{2} \mathrm{NH}_{2}$ & -10.00 & -33.82 & 0.09 \\
\hline $\mathrm{HSO}_{4}^{-}+\left(\mathrm{CH}_{3}\right)_{2} \mathrm{NH} \leftrightarrow \mathrm{HSO}_{4}^{-} \bullet\left(\mathrm{CH}_{3}\right)_{2} \mathrm{NH}$ & -12.73 & -40.15 & -0.76 \\
\hline 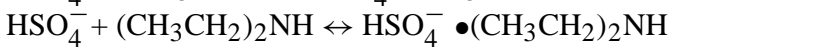 & -14.37 & -43.76 & -0.94 \\
\hline $\mathrm{HSO}_{4}^{-}+\left(\mathrm{CH}_{3}\right)_{3} \mathrm{~N} \leftrightarrow \mathrm{HSO}_{4}^{-} \bullet\left(\mathrm{CH}_{3}\right)_{3} \mathrm{~N}$ & -11.27 & -39.46 & 0.50 \\
\hline $\mathrm{HSO}_{4}^{-}+\left(\mathrm{CH}_{3} \mathrm{CH}_{2}\right)_{3} \mathrm{~N} \leftrightarrow \mathrm{HSO}_{4}^{-} \bullet\left(\mathrm{CH}_{3} \mathrm{CH}_{2}\right)_{3} \mathrm{~N}$ & -13.35 & -44.80 & 0.01 \\
\hline $\mathrm{HSO}_{4}^{-}+\left(\mathrm{CH}_{3} \mathrm{CH}_{2}\right) \mathrm{NH}\left(\mathrm{CH}_{3}\right) \stackrel{4}{\leftrightarrow} \mathrm{HSO}_{4}^{-} \bullet\left(\mathrm{CH}_{3} \mathrm{CH}_{2}\right) \mathrm{NH}\left(\mathrm{CH}_{3}\right)$ & -13.49 & -38.20 & -1.71 \\
\hline
\end{tabular}

clusters, as the free ion is likely to possess an internal rotation degree of freedom (Kurtén et al., 2007b). However, the contribution of this error source is essentially constant, so the relative energetics (e.g. differences in formation free energies between $\mathrm{HSO}_{4}^{-}$-ammonia and $\mathrm{HSO}_{4}^{-}$-amine complexes) are still relatively reliable.
It can be seen from Tables 1 and 2 that the complexes of sulfuric acid and the hydrogensulfate ion with the various amines studied are almost always stronger bound than the corresponding complexes with ammonia. (The sole exception is $\mathrm{HSO}_{4}^{-} \bullet \mathrm{CH}_{3} \mathrm{NH}_{2}$, which is slightly less stable than $\mathrm{HSO}_{4}^{-} \bullet \mathrm{NH}_{3}$ with respect to the electronic energy, though 
not the free energy.) For the neutral dimers, the stabilization effect associated with the substitution of one or more hydrogens of ammonia with alkyl groups is very large, on the order of 5-15 kcal/mol. The magnitude of this effect systematically increases both with the number and size of the alkyl substituents. As expected, the ordering of the complexation free energies for the neutral dimers follows that of the proton affinites reported by Hunter and Lias (1998). However, for the charged dimers, this is not the case. Overall, the stabilization effect is much smaller for the charged clusters, on the order of $0-3 \mathrm{kcal} / \mathrm{mol}$, and while increasing the substituent size still systematically increases the stability of the complex, the dimers containing disubstituted amines are more stable than the dimers containing mono- or trisubstituted amines.

For the neutral complexes, the main reason for the large effect on the formation energies is apparent from Fig. 1: the alkyl groups on the amines are better able to stabilize the positive charge associated with proton transfer from an $\mathrm{SOH}$ group to the nitrogen atom, which leads to the formation of a strongly bound ion pair. For $\mathrm{H}_{2} \mathrm{SO}_{4}-\mathrm{NH}_{3}$ clusters, in contrast, the presence of two sulfuric acids are required for proton transfer to occur (Kurtén et al., 2007a; Nadykto and Yu, 2007). This also explains, on a microscopic level, the growth in stability (and increase in proton affinity) as a function of substituent size and number: larger and more numerous substituents are able to stabilize the positive charge better.

In the case of the $\mathrm{HSO}_{4}^{-}$ion, there is no weakly bound proton to transfer, and the change in stability is correspondingly smaller, as it involves only the strengthening of existing hydrogen bonds instead of the formation of new ion pairs. The decrease in stability in going from di- to trisubstituted amines is probably explained by the fact that while the disubstituted amines can form two hydrogen bonds with $\mathrm{HSO}_{4}^{-}$, the trisubstituted amines can form only one, as they lack the additional hydrogen atom needed for the bond (see Fig. 2). For the neutral complexes, the increased ion pair stabilization in going from di- to trisubstituted amines seems to outweigh the absence of the second, weaker hydrogen bond. However, the difference in stability between dimers containing di- and trisubstituted amines is much smaller than the difference between dimers containing mono- and disubstitude amines, especially in the case of the neutral complexes. While it is very unlikely that the addition of water molecules will change the central conclusion that amines are much more strongly bound to sulfuric acid than ammonia is, hydration may change the bonding patterns seen in Figs. 1-3, and affect the relative stability of different amine-acid clusters. For example, the more highly substituted amines are less hydrophilic than ammonia or the less substituted amines. Thus, accounting for hydration of the clusters is likely to somewhat decrease the differences in stability observed in Tables 1 and 2 .

In order to assess the importance of amines for sulfuric acid-related nucleation processes, it is not enough to know how strongly they are bound to a single sulfuric acid

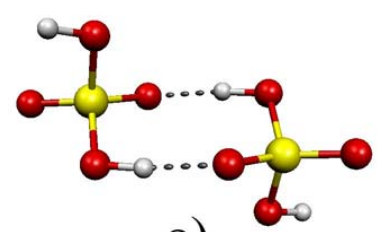

a)

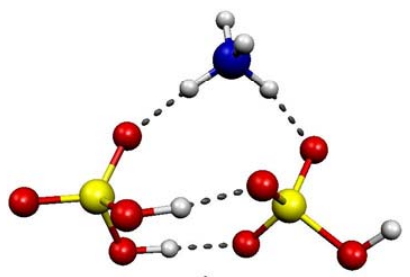

c)

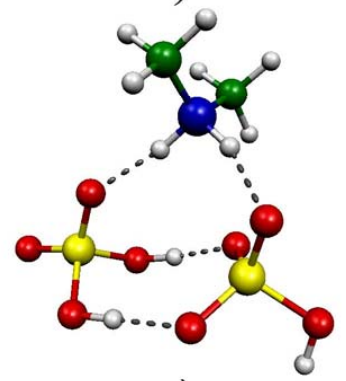

e)

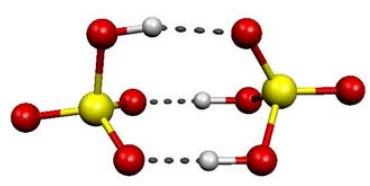

b)

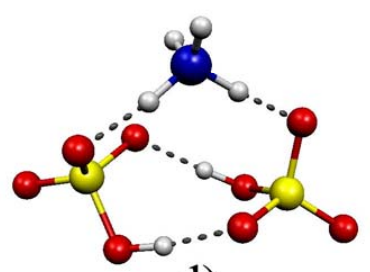

d)

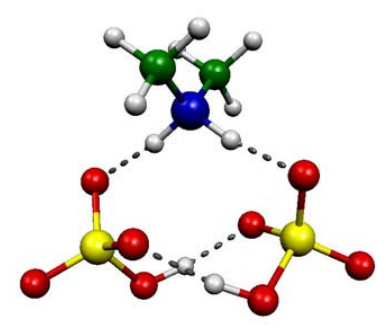

f)
Fig. 3. The structures of most stable cluster structures containing two sulfuric acid molecules or one sulfuric acid and one hydrogensulfate ion: a) $\left(\mathrm{H}_{2} \mathrm{SO}_{4}\right)_{2}$, b) $\mathrm{H}_{2} \mathrm{SO}_{4} \bullet \mathrm{HSO}_{4}^{-}$, c) $\left(\mathrm{H}_{2} \mathrm{SO}_{4}\right)_{2} \bullet \mathrm{NH}_{3}$, d) $\mathrm{H}_{2} \mathrm{SO}_{4} \bullet \mathrm{HSO}_{4}^{-} \bullet \mathrm{NH}_{3}$, e) $\left(\mathrm{H}_{2} \mathrm{SO}_{4}\right)_{2} \bullet\left(\mathrm{CH}_{3}\right)_{2} \mathrm{NH}$, f) $\mathrm{H}_{2} \mathrm{SO}_{4} \bullet \mathrm{HSO}_{4}^{-} \bullet\left(\mathrm{CH}_{3}\right)_{2} \mathrm{NH}$. Hydrogen bonds are indicated by dashed lines. Color coding as in Fig. 1.

molecule (or hydrogensulfate ion). Information on the ability of the amines to promote the addition of further sulfuric acid molecules to the cluster, and thus lower the nucleation barrier, is also required. Toward this end, we have computed reaction free energies for the addition of a sulfuric acid molecule to a cluster containing one sulfuric acid molecule or hydrogensulfate ion together with either ammonia or dimethylamine. Data for the dimer clusters containing only $\mathrm{H}_{2} \mathrm{SO}_{4}$ and $\mathrm{HSO}_{4}^{-}$is provided for reference. Dimethylamine was chosen as a representative amine both due to computational considerations - it is considerably smaller than e.g. triethylamine - and based on the results of Mäkelä et al. (2001) which indicate that it is present in the atmosphere in boreal forest conditions. The results are presented in Tables 3 and 4, while the corresponding lowest-energy cluster structures are shown in Fig. 3. A comparison of Fig. 3 with Tables 3 and 4 shows that even though the structure and binding patterns of the ammonia- and dimethylaminecontaining clusters are similar, dimethylamine enhances the addition of sulfuric acid to the clusters considerably more 
Table 3. Electronic energies computed for the addition of sulfuric acid to various clusters, at different levels of theory. DZ and TZ correspond to aug-cc-pV(D+d)Z and aug-cc-pV(T+d)Z, respectively. All values correspond to geometries optimized at the RI-MP2/aug-cc-pV(D+d)Z level.

\begin{tabular}{lccc}
\hline Reaction & $\begin{array}{c}\Delta E_{0}, \\
\text { RI-MP2/DZ } \\
\text { kcal/mol }\end{array}$ & $\begin{array}{c}\Delta E_{0}, \\
\text { RI-MP2/TZ } \\
\text { kcal/mol }\end{array}$ & $\begin{array}{c}\Delta E_{0}, \\
\text { RI-CC2/TZ } \\
\mathrm{kcal} / \mathrm{mol}\end{array}$ \\
\hline $\mathrm{H}_{2} \mathrm{SO}_{4}+\mathrm{H}_{2} \mathrm{SO}_{4} \leftrightarrow\left(\mathrm{H}_{2} \mathrm{SO}_{4}\right)_{2}$ & -17.99 & -18.97 & -19.04 \\
$\mathrm{H}_{2} \mathrm{SO}_{4} \bullet \mathrm{NH}_{3}+\mathrm{H}_{2} \mathrm{SO}_{4} \leftrightarrow\left(\mathrm{H}_{2} \mathrm{SO}_{4}\right)_{2} \bullet \mathrm{NH}_{3}$ & -29.51 & -30.53 & -31.21 \\
$\mathrm{H}_{2} \mathrm{SO}_{4} \bullet\left(\mathrm{CH}_{3}\right)_{2} \mathrm{NH}+\mathrm{H}_{2} \mathrm{SO}_{4} \leftrightarrow\left(\mathrm{H}_{2} \mathrm{SO}_{4}\right)_{2} \bullet\left(\mathrm{CH}_{3}\right)_{2} \mathrm{NH}$ & -33.66 & -34.38 & -34.41 \\
$\mathrm{HSO}_{4}^{-}+\mathrm{H}_{2} \mathrm{SO}_{4} \leftrightarrow \mathrm{HSO}_{4}^{-} \bullet \mathrm{H}_{2} \mathrm{SO}_{4}$ & -47.11 & -48.87 & -49.05 \\
$\mathrm{HSO}_{4}^{-} \bullet \mathrm{NH}_{3}+\mathrm{H}_{2} \mathrm{SO}_{4} \leftrightarrow \mathrm{HSO}_{4}^{-} \bullet \mathrm{H}_{2} \mathrm{SO}_{4} \bullet \mathrm{NH}_{3}$ & -49.68 & -50.27 & -51.23 \\
$\mathrm{HSO}_{4}^{-} \bullet\left(\mathrm{CH}_{3}\right)_{2} \mathrm{NH}+\mathrm{H}_{2} \mathrm{SO}_{4} \leftrightarrow \mathrm{HSO}_{4}^{-} \bullet \mathrm{H}_{2} \mathrm{SO}_{4} \bullet\left(\mathrm{CH}_{3}\right)_{2} \mathrm{NH}$ & -59.01 & -58.39 & -59.40 \\
\hline
\end{tabular}

Table 4. Enthalpies, entropies and Gibbs free energies computed for the addition of sulfuric acid to various ammonia or dimethylaminecontaining clusters, at $298 \mathrm{~K}$ and 1 atm reference pressure for all reactants. All values correspond to RI-MP2/aug-cc-pV(D+d)Z geometries and harmonic vibrational frequencies and RI-CC2/aug-cc-pV(T+d)Z electronic energies.

\begin{tabular}{lccc}
\hline Reaction & $\begin{array}{c}\Delta H(298 \mathrm{~K}) \\
\mathrm{kcal} / \mathrm{mol}\end{array}$ & $\begin{array}{c}\Delta S(298 \mathrm{~K}) \\
\mathrm{cal} / \mathrm{Kmol}\end{array}$ & $\begin{array}{c}\Delta G(298 \mathrm{~K}) \\
\mathrm{kcal} / \mathrm{mol}\end{array}$ \\
\hline $\mathrm{H}_{2} \mathrm{SO}_{4}+\mathrm{H}_{2} \mathrm{SO}_{4} \leftrightarrow\left(\mathrm{H}_{2} \mathrm{SO}_{4}\right)_{2}$ & -17.81 & -36.51 & -6.93 \\
$\mathrm{H}_{2} \mathrm{SO}_{4} \bullet \mathrm{NH}_{3}+\mathrm{H}_{2} \mathrm{SO}_{4} \leftrightarrow\left(\mathrm{H}_{2} \mathrm{SO}_{4}\right)_{2} \bullet \mathrm{NH}_{3}$ & -28.74 & -48.00 & -14.43 \\
$\mathrm{H}_{2} \mathrm{SO}_{4} \bullet\left(\mathrm{CH}_{3}\right)_{2} \mathrm{NH}_{+} \mathrm{H}_{2} \mathrm{SO}_{4} \leftrightarrow\left(\mathrm{H}_{2} \mathrm{SO}_{4}\right)_{2} \bullet\left(\mathrm{CH}_{3}\right)_{2} \mathrm{NH}$ & -32.70 & -44.97 & -19.29 \\
$\mathrm{HSO}_{4}^{-}+\mathrm{H}_{2} \mathrm{SO}_{4} \leftrightarrow \mathrm{HSO}_{4}^{-} \bullet \mathrm{H}_{2} \mathrm{SO}_{4}$ & -48.20 & -47.29 & -34.10 \\
$\mathrm{HSO}_{4}^{-} \bullet \mathrm{NH}_{3}+\mathrm{H}_{2} \mathrm{SO}_{4} \leftrightarrow \mathrm{HSO}_{4}^{-} \bullet \mathrm{H}_{2} \mathrm{SO}_{4} \bullet \mathrm{NH}_{3}$ & -49.57 & -45.39 & -34.75 \\
$\mathrm{HSO}_{4}^{-} \bullet\left(\mathrm{CH}_{3}\right)_{2} \mathrm{NH}+\mathrm{H}_{2} \mathrm{SO}_{4} \leftrightarrow \mathrm{HSO}_{4}^{-} \bullet \mathrm{H}_{2} \mathrm{SO}_{4} \bullet\left(\mathrm{CH}_{3}\right)_{2} \mathrm{NH}$ & -56.94 & -49.93 & -42.05 \\
\hline
\end{tabular}

effectively than ammonia, with the difference in reaction free energies being approximately $5 \mathrm{kcal} / \mathrm{mol}$ for the neutral clusters and $7 \mathrm{kcal} / \mathrm{mol}$ for the charged clusters. Especially the latter results is significant, as it implies that, despite the low attraction between the various amines and the $\mathrm{HSO}_{4}^{-}$ion, amines, unlike ammonia, might still enhance ion-induced sulfuric acid nucleation. This is especially relevant given the suggestion by Laakso et al. (2007) that some third compound besides sulfuric acid and water is needed to explain the observed ion-induced contribution to nucleation events in the boreal forest.

Beside thermodynamic data at standard conditions, information on the concentrations of the reactant species is also required to determine the atmospheric role of sulfuric acidamine cluster formation. From the law of mass balance, the ratio of the concentrations of e.g. dimethylamine - containing clusters to ammonia - containing clusters can be expressed as:

$$
\frac{\left[\mathrm{X} \bullet\left(\mathrm{CH}_{3}\right)_{2} \mathrm{NH}\right]}{\left[\mathrm{X} \bullet \mathrm{NH}_{3}\right]}=\frac{\left[\left(\mathrm{CH}_{3}\right)_{2} \mathrm{NH}\right]}{\left[\mathrm{NH}_{3}\right]} e^{\frac{-\Delta \Delta G_{0}}{R T}}
$$

where $\mathrm{X}$ indicates some cluster composition (e.g. $\mathrm{H}_{2} \mathrm{SO}_{4} \bullet \mathrm{H}_{2} \mathrm{SO}_{4}$ or $\mathrm{H}_{2} \mathrm{SO}_{4} \bullet \mathrm{HSO}_{4}^{-}$), $T$ is the temperature in Kelvin, $R$ is the molar gas constant and $\Delta \Delta G_{0}$ is the difference in the standard free energies of formation for the $\mathrm{X} \bullet\left(\mathrm{CH}_{3}\right)_{2} \mathrm{NH}$ and $\mathrm{X} \bullet \mathrm{NH}_{3}$ clusters. Thus, if the gas-phase concentration of dimethylamine is e.g. 100-1000 times smaller than the concentration of ammonia, the formation free energies for the dimethylamine-containing clusters must be more than $3-4 \mathrm{kcal} / \mathrm{mol}$ lower than that of the ammonia-containing clusters for their concentrations to be equal.

Unfortunately, there is very little data on the atmospheric concentrations of any amine species. According to Schade and Crutzen (1995), the combined global emissions of methylamine, dimethylamine and trimethylamine in 1988 were $150 \pm 60 \mathrm{TgN}$, about $3 / 4$ of which consisted of trimethylamine. This corresponds to about $1 / 150$ of the global ammonia emissions, implying that, on average, amine concentrations are at least two orders of magnitude lower than those of ammonia. As ammonia concentrations in continental air are typically in the $0.1-10 \mathrm{ppb}$ range (Seinfeld and Pandis, 1998), this would indicate that amine concentrations are on the order of 1-100 ppt. Because amines are more rapidly oxidized by $\mathrm{OH}$ than ammonia, this should probably be considered an upper limit, and far from the emission sources the amine- to ammonia-concentration ratio may be 
Table 5. Ratio of the concentrations of dimethylamine-containing to ammonia-containing neutral and ionic trimer clusters, as a function of the gas-phase concentration ratio of dimethylamine to ammonia in a hypothetical steady-state situation, based on the free energies of complex formation given in Tables 2 and 4.

\begin{tabular}{lll}
\hline $\begin{array}{l}{\left[\left(\mathrm{CH}_{3}\right)_{2} \mathrm{NH}\right] /\left[\mathrm{NH}_{3}\right]} \\
\text { ratio }\end{array}$ & $\begin{array}{l}{\left[\left(\mathrm{H}_{2} \mathrm{SO}_{4}\right)_{2} \bullet\left(\mathrm{CH}_{3}\right)_{2} \mathrm{NH}\right] /} \\
{\left[\left(\mathrm{H}_{2} \mathrm{SO}_{4}\right)_{2} \bullet \mathrm{NH}_{3}\right]} \\
\text { ratio }\end{array}$ & $\begin{array}{l}{\left[\mathrm{HSO}_{4}^{-} \bullet \mathrm{H}_{2} \mathrm{SO}_{4} \bullet\left(\mathrm{CH}_{3}\right)_{2} \mathrm{NH}\right] /} \\
{\left[\mathrm{HSO}_{4}^{-} \bullet \mathrm{H}_{2} \mathrm{SO}_{4} \bullet \mathrm{NH}_{3}\right]} \\
\text { ratio }\end{array}$ \\
\hline $1: 10$ & $5.2 \times 10^{7}: 1$ & $1.5 \times 10^{6}: 1$ \\
$1: 100$ & $5.2 \times 10^{6}: 1$ & $1.5 \times 10^{5}: 1$ \\
$1: 1000$ & $5.2 \times 10^{5}: 1$ & $1.5 \times 10^{4}: 1$ \\
$1: 10000$ & $5.2 \times 10^{4}: 1$ & $1.5 \times 10^{3}: 1$ \\
\hline
\end{tabular}

even smaller. However, at a boreal forest site in Hyytiälä, Finland, trimethylamine concentrations during a spring measurement campaign (Sellegri et al., 2005) varied between 34 and $80 \mathrm{ppt}$, indicating that the order-of-magnitude estimate above may be roughly correct. Close to amine emission sources, concentrations may be much higher, e.g. diethylamine and butylamine concentrations of over $100 \mathrm{ppb}$ have been reported in the vicinity of a dairy farm in California (Rabaud et al., 2003).

These measurements and estimates show that the number concentration of amine molecules may well be equal to or greater than that of sulfuric acid, which typically has concentrations of $10^{7}$ molecules $\mathrm{cm}^{-3}$ (corresponding to $0.4 \mathrm{ppt}$ at $298 \mathrm{~K}$ ) or less in non-polluted areas (Spracklen et al., 2006). Even for amine concentrations as low as $1 \mathrm{ppt}$, the collision rate of amine and sulfuric acid molecules would thus still be on the order of $10^{4}-10^{5}$ collisions $\mathrm{cm}^{-3} \mathrm{~s}^{-1}$, indicating that the formation of atmospherically significant amounts of amine-sulfuric acid clusters is at least not ruled out by collision kinetics. Still, in these conditions each sulfuric acid molecule or small cluster collides with an amine molecule only every $100 \mathrm{~s}$ or so, implying that while amines are likely to play a significant role in the initial steps of nucleation, their role in subsequent particle growth is likely to be minor. This is in line with atmospheric observations which indicate that the vapors responsible for the formation of $1 \mathrm{~nm}$ - scale particles are not the same as those responsible for the growth of particles (Kulmala et al., 2007).

Using the Eq. (1) together with free energies for complexation given in Tables 2 and 4, we have computed the ratio of the concentrations of $\left(\mathrm{H}_{2} \mathrm{SO}_{4}\right)_{2} \bullet\left(\mathrm{CH}_{3}\right)_{2} \mathrm{NH}$ to $\left(\mathrm{H}_{2} \mathrm{SO}_{4}\right)_{2} \bullet \mathrm{NH}_{3}$ and $\mathrm{HSO}_{4}^{-} \bullet \mathrm{H}_{2} \mathrm{SO}_{4} \bullet\left(\mathrm{CH}_{3}\right)_{2} \mathrm{NH}$ to $\mathrm{HSO}_{4}^{-} \bullet \mathrm{H}_{2} \mathrm{SO}_{4} \bullet \mathrm{NH}_{3}$ clusters as a function of the ratio of ammonia and dimethylamine concentrations. As the concentration ratios do not depend strongly on the temperature, results are shown only for $298 \mathrm{~K}$. The results are presented in Table 5. It can be seen from Table 5 that even if the concentration of gas-phase dimethylamine is only one thousandth of the ammonia concentration, amine-containing clusters are still likely to dominate the cluster distribution. However, the application of Eq. (1) presumes a pseudo-steady-state situation, where the formation of complexes does not significantly deplete the gas-phase reservoir of reactant molecules. For very low absolute amine concentrations, this is almost certainly not the case: the formation of sulfuric acid-amine clusters will then quickly deplete the amine reservoir, and steady-state conditions will not apply. The results presented here should therefore be considered as qualitative order-of-magnitude assessments. A quantitatively reliable determination of the relative atmospheric importance of amine- and ammonia-containing clusters would require both much more reliable concentration data as well as fully kinetic nucleation simulations, which are beyond the scope of this study.

Previously, it has been thought that vegetation influences new-particle formation mainly via the emission of various types of terpenes, which are oxidized in the atmosphere to form condensable vapors (Kulmala et al., 2004b). These vapors may then participate in nucleation (O'Dowd et al., 2002), e.g. via reacting or clustering with sulfuric acid molecules. As vegetation is a also source of amines, a nucleation mechanism involving enhancement of sulfuric acidwater nucleation by biogenic amines would provide another link between biogenic vapor emissions from forests and particle formation. The results presented here indicate that the stable pool of $1.5-1.8 \mathrm{~nm}$ neutral clusters observed by Kulmala et al. (2007) in boreal forest conditions are likely to contain contributions from amine-sulfuric acid clustering rather than ammonia-sulfuric acid clustering reactions.

\section{Conclusions}

The dimer clusters of ammonia and seven different amine species with $\mathrm{H}_{2} \mathrm{SO}_{4}$ and $\mathrm{HSO}_{4}^{-}$were studied using the RIMP2 and RI-CC2 methods. Further calculations were performed on trimer clusters containing ammonia or dimethylamine together with two $\mathrm{H}_{2} \mathrm{SO}_{4}$ molecules or one $\mathrm{H}_{2} \mathrm{SO}_{4}$ molecule and one $\mathrm{HSO}_{4}^{-}$ion. The computed free energies for complex formation show that amines are considerably 
more effective than ammonia in enhancing the addition of sulfuric acid molecules to both neutral and ionic sulfuric acid clusters. This is especially relevant for the ionic clusters, as previous experimental and theoretical studies indicate that in addition to sulfuric acid and water, the participation of some third compound, other than ammonia, is needed to explain the ion-induced contribution to observed nucleation rates. Our results indicate that both neutral and ion-induced nucleation mechanisms involving sulfuric acid are likely to be enhanced much more effectively by amines than by ammonia, even after the differences in their atmospheric concentrations are accounted for. Quantitative determination of the effect of amines on sulfuric acid-water nucleation, and especially the relative effect of different amines, will require the explicit modeling of amine-sulfuric acid cluster hydration, which is beyond the scope of the present paper.

Acknowledgements. We acknowledge the Scientific Computing Center (CSC) in Espoo, Finland for computing time and the Academy of Finland for financial support. Furthermore, we wish to thank Martta Salonen for useful assistance.

Edited by: A. Wiedensohler

\section{References}

Ahlrichs, R., Bär, M., Häser, M., Horn, H., and Kölmel, C.: Electronic structure calculations on workstation computers: The program system Turbomole, Chem. Phys. Lett., 162, 165-169, 1989.

Angelino, A., Suess, D. T., and Prather, K.: Formation of Aerosol Particles from Reactions of Secondary and Tertiary Alkylamines: Characterization by Aerosol Time-of-Flight Mass Spectrometry, Environ. Sci. Technol. 35, 3130-3138, 2001.

Anttila, T., Vehkamäki, H., Napari, I., and Kulmala, M.: Effect of ammonium bisulphate formation on atmospheric water-sulphuric acid-ammonia nucleation, Boreal Env. Res., 10, 511-523, 2005.

Ball, S. M., Hanson, D. R., Eisele, F. L. , and McMurry, P. H.: Laboratory studies of particle nucleation: Initial results for $\mathrm{H}_{2} \mathrm{SO}_{4}$, $\mathrm{H}_{2} \mathrm{O}$, and $\mathrm{NH}_{3}$ vapors, J. Geophys. Res. D, 104, 23 709-23 718, 1999.

Christiansen, O., Koch, H., and Jørgensen, P.: The second-order approximate coupled cluster singles and doubles model CC2, Chem. Phys. Lett., 243, 409-418, 1995.

Dunning Jr., T. H., Peterson, K. A., and Wilson, A. K.: Gaussian basis sets for use in correlated molecular calculations. X. The atoms aluminum through argon revisited, J. Chem. Phys., 114, 9244-9253, 2001.

Feller, A. D.: Application of systematic sequences of wave functions to the water dimer, J. Chem. Phys., 96, 6104-6114, 1992.

Hunter, E. P. and Lias, S. G.: Evaluated Gas Phase Basicities and Proton Affinities of Molecules: An Update, J. Phys. Chem. Ref. Data, 27, 413-656 (data available online via the NIST Chemistry WebBook), 1998.

Häser, M. and Ahlrichs, R: Improvements on the direct SCF method, J. Comput. Chem., 10, 104-111, 1989.

Korhonen, P., Kulmala, M., Laaksonen, A., Viisanen, Y., McGraw, R., and Seinfeld, J. H.: Ternary nucleation of $\mathrm{H}_{2} \mathrm{SO}_{4}, \mathrm{NH}_{3}$, and
$\mathrm{H}_{2} \mathrm{O}$ in the atmosphere, J. Geophys. Res., 104, 26349-26353, 1999.

Kulmala, M., Pirjola, L., and Mäkelä, J. M.: Stable sulphate clusters as a source of new atmospheric particles, Nature, 404, 66-69, 2000.

Kulmala, M., Vehkamäki, H., Petäjä, T., Dal Maso, M., Lauri, A., Kerminen, V.-M., Birmili, W., and McMurry, P. H.: Formation and growth rates of ultrafine atmospheric particles: a review of observations, J. Aerosol Sci., 35, 143-176, 2004a.

Kulmala, M., Suni, T., Lehtinen, K. E. J., Dal Maso, M., Boy, M., Reissell, A., Rannik, Ü., Aalto, P., Keronen, P., Hakola, H., Bäck, J., Hoffmann, T., Vesala, T., and Hari, P.: A new feedback mechanism linking forests, aerosols, and climate, Atmos. Chem. Phys., 4, 557-562, 2004b,

http://www.atmos-chem-phys.net/4/557/2004/.

Kulmala, M., Riipinen, I., Sipilä, M., Manninen, H. E., Petäjä, T., Junninen, H., Dal Maso, M., Mordas, G., Mirme, A., Vana, M., Hirsikko, A., Laakso, L., Harrison, R. M., Hanson, I., Leung, C., Lehtinen, K. E. J., and Kerminen, V.-M.: Towards Direct Measurement of Atmospheric Nucleation, Science, 318, 89-92, 2007.

Kurtén, T., Torpo, L., Ding, C.-G., Vehkamäki, H., Sundberg, M. R., Laasonen, K., and Kulmala, M.: A density functional study on water-sulfuric acid-ammonia clusters and implications for atmospheric cluster formation, Geophys. Res., 112, D04210, doi:10.1029/2006JD007391, 2007a.

Kurtén, T., Noppel, M., Vehkamäki, H., Salonen, M., and Kulmala, M.: Quantum chemical studies of hydrate formation of $\mathrm{H}_{2} \mathrm{SO}_{4}$ and $\mathrm{HSO}_{4}^{-}$, Boreal Env. Res., 12, 431-453, $2007 \mathrm{~b}$.

Kurtén, T., Torpo, L., Sundberg, M. R., Vehkamäki, H., and Kulmala, M: Estimation of the $\mathrm{NH}_{3}: \mathrm{H}_{2} \mathrm{SO}_{4}$ ratio of nucleating clusters in atmospheric conditions using quantum chemical methods, Atmos. Chem. Phys., 7, 2765-2773, 2007c, http://www.atmos-chem-phys.net/7/2765/2007/.

Laakso, L., Grönholm, T., Kulmala, L., Haapanala, S., Hirsikko, A., Lovejoy, E. R., Kazil, J., Kurtén, T., Boy, M., Nilsson, E. D., Sogachev, A., Riipinen, I., Strattman, F., and Kulmala, M.: Hotair balloon measurements of vertical variation of boundary layer new particle formation, Boreal Env. Res., 12, 279-294, 2007.

Lovejoy, E. R., Curtius, J., and Froyd, K. D.: Atmospheric ioninduced nucleation of sulfuric acid and water, J. Geophys. Res., 109, D08204, doi:10.1029/2003JD004460, 2004.

Mäkelä, J. M., Yli-Koivisto, S., Hiltunen, V., Seidl, W., Swietlicki, E., Teinilä, K., Sillanpää, M., Koponen, I. K., Paatero, J., Rosman, K., and Hämeri, K.: Chemical composition of aerosol during particle formation events in boreal forest, Tellus, 53B, 380393, 2001.

Murphy, S. M., Sorooshian, A., Kroll, J. H., Ng, N. L., Chhabra, P., Tong, C., Surratt, J. D., Knipping, E., Flagan, R. C., and Seinfeld, J. H: Secondary aerosol formation from atmospheric reactions of aliphatic amines, Atmos. Chem. Phys., 7, 2313-2337, 2007, http://www.atmos-chem-phys.net/7/2313/2007/.

Nadykto, A. B. and Yu, F.: Strong hydrogen bonding between atmospheric nucleation precursors and common organics, Chem. Phys. Lett., 435, 14-18, 2007.

O’Dowd, C. D., Aalto, P., Hämeri, K., Kulmala, M., and Hoffmann, T.: Atmospheric particles from organic vapours, Nature, 416, 497-498, 2002.

Ortega, I. K., Kurtén, T., Vehkamäki, H., and Kulmala, M: The Role 
of Ammonia in Sulfuric Acid Ion-Induced Nucleation, Atmos. Chem. Phys., 8, 2859-2867, 2008,

http://www.atmos-chem-phys.net/8/2859/2008/.

Portmann, S.: MOLEKEL, Version 4.3.win32. Swiss Center for Scientific Computing (CSCS)/ETHZ, Switzerland, 2002.

Rabaud, N. E., Ebeler, S. E., Ashbaugh, L. L., and Flocchini, R. G.: Characterization and quantification of odorous and non-odorous volatile organic compounds near a commercial dairy in California, Atmos. Environ., 37, 933-940, 2003.

Schade, G. W. and Crutzen, P. J.: Emission of aliphatic amines from animal husbandry and their reactions: Potential source of $\mathrm{N}_{2} \mathrm{O}$ and HCN, J. Atmos. Chem. 22, 319-346, 1995.

Seinfeld, J. H. and Pandis, S. N.: Atmospheric Chemistry and Physics: From Air Pollution to Climate Change, Wiley \& Sons, New York, USA, 1998.

Sellegri, K., Hankel, M, Umann, B., Arnold, F., and Kulmala, M.: Measurements of organic gases during aerosol formation events in the boreal forest atmosphere during QUEST, Atmos. Chem. Phys., 5, 373-384, 2005,

http://www.atmos-chem-phys.net/5/373/2005/.
Spracklen, D. V., Carslaw, K. S., Kulmala, M., Kerminen, V.-M., Mann, G. W., and Sihto, S.-L.: The contribution of boundary layer nucleation events to total particle concentrations on regional and global scales, Atmos. Chem. Phys., 6, 5631-5648, 2006, http://www.atmos-chem-phys.net/6/5631/2006/.

Torpo, L., Kurtén, T., Vehkamäki, H., Sundberg, M. R., Laasonen, K., and Kulmala, M.: The significant role of ammonia in atmospheric nanoclusters, J. Phys. Chem. A, 111, 10 671-10 674, 2007.

Weigend, F. and Häser, M: RI-MP2: first derivatives and global consistency, Theor. Chem. Acc., 97, 331-340, 1997.

Weigend, F., Häser, M., Patzelt, H., and Ahlrichs, R.: RI-MP2: Optimized auxiliary basis sets and demonstration of efficiency, Chem. Phys. Lett., 294, 143-152, 1998.

Weigend, F., Köhn, A., and Hättig, C.: Efficient use of the correlation consistent basis sets in resolution of the identity MP2 calculations, J. Chem. Phys., 116, 3175-3183, 2002. 